CS Silje Susanne Alvestad (ed.) Comparative Slavic Syntax and Semantics, Oslo Studies in Language 9(1), 2017. 33-43. (ISSN 1890-9639 / ISBN 978-82-91398-12-9)

http://www.journals.uio.no/osla

\title{
MOVEMENT OUT OF ADJUNCT CLAUSES IN RUSSIAN: EVIDENCE FROM SEMANTICS
}

\author{
DANIEL TISKIN \\ Saint Petersburg State University
}

\section{ABS TRACT}

Although in most familiar cases sentential adjuncts are islands, syntactic evidence for overt movement out of adjunct clauses in Russian has been around for a while. The present paper makes a case for covert (LF) movement out of conditionals. The data is the same as Ivlieva (2011) used to motivate her 'laziness' theory of pronouns bound by universal antecedents. The analysis proposed here exploits the possibility of movement out of conditionals (manifest in overt syntax elsewhere), in particular that of Acrossthe-Board extraction out of both the protasis and the apodosis.

\section{[1] INTRODUCTION}

Finite adjunct clauses are generally believed to be strong islands for syntactic movement (Szabolcsi \& den Dikken 2003, 214), i.e. no constituent may cross the border of an adjunct while moving:

(1) $*$ [Which college $]_{i}$ did you become a linguist [after you entered $\left.t_{i}\right]$ ?

There are several known sorts of exceptions from this constraint. First, several languages (Japanese, Korean, Malayalam) have been reported to be exempted from the restriction (Yoshida 2006). Second, English rationale clauses are not subject to it (Culicover 1997, 253), as Culicover's (2) witnesses. Besides that, Barker (2012) provides numerous examples where the binding relation does not observe c-command, including (3) and the like (see his §3.7), although on his account those are no exceptions as his proposed replacement for the c-command requirement rests on the notion of 'the order of evaluation'.

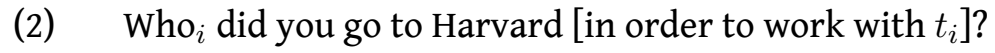

(3) After unthreading each $_{i}$ screw, but before removing it $_{i}$, make sure to hold the screw in place while separating the screw from the driver.

In what follows, I will survey other exceptional cases, mostly known data from Russian. Purely syntactic arguments will, however, serve a somewhat ancillary role, as the main body of evidence to be dealt with below is of semantic nature: LF 
movement out of an alleged island will be a likely explanation for the perceived semantics.

The rest of the paper is organised in the following way. Section [2] introduces the cases of overt extraction from adjuncts in Russian. Section [3] is dedicated specifically to extraction out of conditionals. In Section [4] I finally turn to Ivlieva's examples, which are presented in [4.1] and analysed in terms of covert ATB movement in [4.2]. A brief conclusion follows.

\section{[2] RUSSIAN AND THE CONSTRAINTS ON EXTRACTION}

In case of conjunction islands, where it is not typically possible to extract from one of the conjuncts (but see the discussion below), the option for extraction is Across-the-Board (ATB) movement, i.e. simultaneous extraction from all conjuncts which results in a single higher copy binding two or more traces (de Vries to appear). This strategy is readily available in Russian (4), but alongside with it there exist cases of 'semantically asymmetric coordination' (like in English, Lakoff 1986) where some of the conjuncts simply lack the target of extraction (5).

$$
\begin{aligned}
& \text { Eto čaj, } \text { kotoryj }_{i} \text { ty zavaril } t_{i} \text {, no ne dopil } t_{i} \text {. } \\
& \text { this tea which you made but not finished.drinking } \\
& \text { 'This is the tea made you but didn't finish drinking' }
\end{aligned}
$$

(5) Eto čaj, kotoryj $i$ ty ušël $v$ kino i ne dopil $t_{i}$.

this tea which you left to cinema and not finished.drinking

lit. 'This is the tea you went to the cinema and didn't finish drinking' (Zaliznyak \& Paducheva 1979)

Relative clauses in Russian are more permissive with respect to extraction than questions (Testelets 2001; Lyutikova 2009):

(6) ${ }^{*} \mathrm{Kogo}_{i}$ Safronyč znal, kak zovut $t_{i} \mathrm{v}$ dome Pektoralisa?

whom S. knew how they.call in house P.GEN

lit. 'Who did Safronych know how were called in Pektoralis' house?'

(7) Safronyč kričal, klikal vsex, $\quad \operatorname{kogo}_{i}$ pro znal, kak zovut $t_{i} \mathrm{v}$ dome S. cried called everyone whom knew how they.call in house Pektoralisa...

P.GEN

lit. 'Safronych cried, calling whoever he knew how were called in Pektoralis' house...' (RNC, ${ }^{1}$ Nikolai Leskov, Lyutikova's example)

In what follows, I restrict myself to relativisation.

[1] Russian National Corpus, http://www.ruscorpora.ru/. 


\section{[3] EXTRACTION OUT OF CONDITIONALS IN THE SYNTAX}

Turning to conditionals, one should note that in Russian a conditional may be expressed at least in two ways: either the clause expressing the consequent of the conditional is structurally identical to a free-standing main clause, or alternatively it contains a correlative conjunction to (or tak). Given that there have been proposals making use of the affinities between conditionals and correlatives (see Bhatt \& Pancheva 2006; Lipták 2009), an anonymous reviewer has suggested that the two cases be considered separately. ${ }^{2}$ However, as regards the possibility of extraction, both types allow for it, ${ }^{3}$ although, judging by the RNC data, with non-ATB extraction the correlative strategy is preferred. (The same is true for temporal adjuncts with kogda, which also occasionally form a correlative configuration; see

[2] Should any of the types (or both) be assimilated to correlatives, the extraction analysis would not have to be abandoned, as extraction out of correlatives is attested in Russian as well. It may target either the relative clause (i) or the correlate (ii), or both, in which case the differences in case-marking force the use of a resumptive pronoun (iii).

(i) V komnate, gde ja spal, byla odna kojka, [na kotoruju] $]_{i}$ kto ljažet spat' $t_{i}$, tot in room where I slept was one bed on which wholies.down to.sleep that.one zabolevajet gorjačkoj...

falls.ill fever.INs

'In the room where I slept, there was one bed such that whoever lay down on it to sleep fell ill with fever...' (RNC)

(ii)

...o vsex <...> mestečkax, v kotoryx, kto znaet, tot mnogo možet najti. about all little.corners in which who knows that.one much can find

'...of all <...> little corners where, if you know, you can find quite a lot' (RNC, Fyodor Dostoevsky)

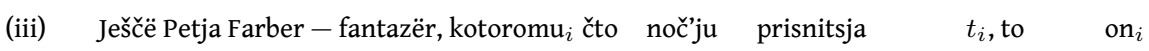
also P.F. dreamer whom what night.Ins appears.in.dream that.one he

dnëm i vykladyvajet.

day.INS PRT tells.out.loud

'It is also that Petya Farber is a dreamer such that what(ever) he sees in his night dreams he would tell out loud in the daylight' (Google)

[3] For a survey on extraction from adjuncts in English, see Chaves (2013, 293). In addition, Yoshida (2006) shows the possibility of extraction from if -islands in Japanese, and Etxepare $(2013,489)$ provides an analogous example for Spanish, claiming that the conditional has to be indicative, as opposed to subjunctive, for the extraction to be possible. In the case of Russian, this does not seem to be a firm restriction (i), and in addition extraction is possible with infinitives (ii):

(i)

...vnutrennego smexa, kotoryj esli by oni uslyšali, tak $\mathrm{v}$ moment by umerli... inner laughter which if sUBJ they heard CORR in moment suBJ died '...inner laughter such that if they heard it, they would die immediately...' (RNC)

(ii) ?A $\mathrm{v}$ seredine cvetka sprjatano čislo, $\mathrm{k}$ kotoromu jesli pribavit' 2, to polučitsja and in middle.LOc flower.gen hidden number to which if add.INF 2 then will.result 10.

10

'And in the middle of the flower, there is hidden a number s.t. if you add 2 to it, the result will be 10' (Google) 
Lyutikova (2009).) A resumptive pronoun may optionally replace the trace (9).

(8) Kakie est' igry $\mathrm{v}$ kotoryx esli vyigral odin - vyigrali i vse ostal'nye? which are games in which if won one won PRT all others 'Which games are there s.t. if one wins, the others win as well?' (Google)

(9) ...nekotorye bukvy byli u nego favority, [do kotoryx $]_{i}$ esli on some characters were PREP he.GEN favourites to which if he dobiralsja $t_{i}$, to byl sam ne svoj... got then was very happy '...some letters were even favourites with him; and when he encountered these, [he got very happy]...' (RNC, Nikolai Gogol)

What is perhaps more surprising, movement out of adjuncts may take place from both clauses. ${ }^{4}$ If cases such as (10) are treated as exemplifying ATB extraction, they will violate the usually assumed symmetry requirement for ATB (but see an overview of other sorts of asymmetries in de Vries to appear, 2.2):

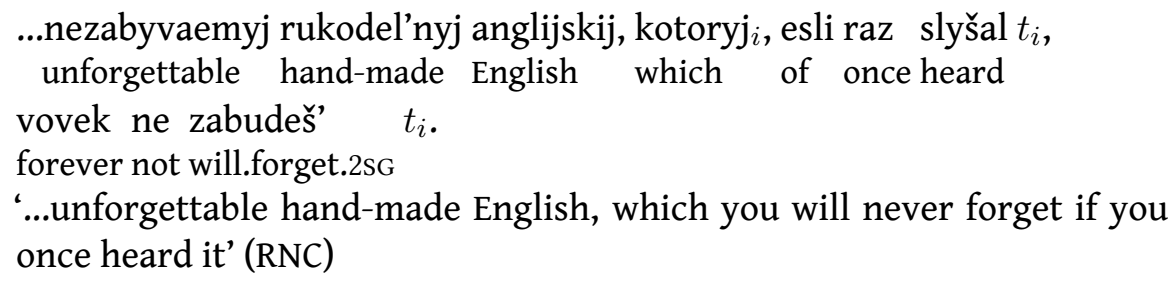
unforgettable hand-made English which of once heard vovek ne zabudeš' $t_{i}$. forever not will.forget.2sG

'...unforgettable hand-made English, which you will never forget if you once heard it' (RNC)

Besides ATB-based analyses, in Williams (1990) one finds an approach to the phenomenon of parasitic gaps (pgs), as exemplified by Williams' (11), via ATB movement. (This approach was later criticised by Postal (1993), largely on the basis of pgs being more restricted in distribution than ATB movement.) As long as ATB, as it is usually conceived, requires coordination, Williams proposed to view conjunctiveness as a continuum based on syntactic as well as semantic considerations. The more 'conjunctive' the structure is, the easier it is to extract ATB.

(11) Who ${ }_{i}$ would you warn $t_{i}$ before striking $p g_{i}$ ?

On the other hand, Ivlieva (2007) proposed to extend the notion of a pg onto cases where no overt movement has taken place (12). Ivlieva assumes the covert $\mathrm{A}^{\prime}$ movement of the gap's antecedent into the Topic position and hints to the possibility of cross-linguistic variation in the overtness of movement operations.

[4] Vicente (2016) interprets the following example, due to Andreas Kathol, as a case of ATB movement without coordination: 
(12) Ja vybrosil [ètu knigu $]_{i}$, ne pročitav $e_{i}$

I threw.away this book not having.read

"I have thrown away this book without reading it'

[4] 'UNIVERSAL LAZINESS' AS COVERT EXTRACTION

Having surveyed the possibilities for overt extraction from conditional clauses in Russian, we may now turn to a semantic puzzle discovered by Natalia Ivlieva (as presented in Ivlieva 2011). She has noted that a pronoun in the main clause of a conditional may be anaphoric on a universal antecedent in the conditional clause. I will show that Ivlieva's account is not unproblematic and propose another view which puts Ivlieva's cases in line with the data presented above.

\section{[4.1] Unbound anaphora in conditionals}

Consider Ivlieva's example, given in (13). The pronoun in the second clause is anaphoric on the DP každyj 'everyone' in the first clause, although universal antecedents have not been previously recognised as suitable antecedents for unbound anaphora ${ }^{5}$ (except for telescoping; see fn. 10). Moreover, the perceived truth conditions for one reading of (13) are stronger than expected on the assumption that if-clauses are islands for LF movement. What (13) says on that reading is, roughly, 'whoever minds his own business will be more useful and, in particular, if it so happens that everyone minds his own business, then everyone will be more useful'; in other words, the relative scope is $\forall>$ if.

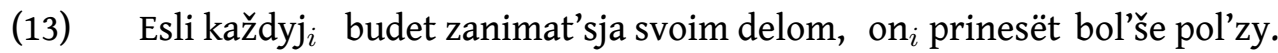
if everyonewill do own business he bring.Fut more use 'If everyone ${ }_{i}$ minds his own business, he ${ }_{i}$ will be more useful'

Ivlieva claims that (13) has two readings. The other reading is weaker and amounts to the ' if $>\forall$ ' pattern. To isolate the weaker reading, Ivlieva provides an intricate scenario. Suppose there are two brothers and two sisters. Then the main clause of (14) is true only if two marriages happen; one is insufficient. Therefore, the reading 'whoever marries...' is excluded, and only the weak reading remains.

(14) Esli by každyj $_{i}$ iz nix ženilsja na odnoj iz sestër, ego brat $_{i}$ if would every of them marry PREP one of sisters his brother stal by ego $_{i}$ svojakom.

become would his brother-in-law

'If each ${ }_{i}$ of them married one of the sisters, his ${ }_{i}$ brother would become his $_{i}$ brother-in-law'

[5] Cf.: 'Generally <...> it is concluded that the universal quantifier shares <...> the characteristic of being externally static' (Groenendijk \& Stokhof 1991, 51). 
Ivlieva assumes that Quantifier Raising (QR) is clause-bound, but even granted that it is not, $Q R$ together with binding into the main clause gives only the stronger reading. Thus Ivlieva's own account is spelled out in terms of pronouns of laziness (Nouwen submitted, i.a.), i.e. pronouns that 'go proxy' for their antecedents, so that the meaning of the sentence may be recovered by substituting a copy of the antecedent for the pronoun. ${ }^{6}$ Given this, (13) is regarded as a shorthand for

(15) Esli každyj budet zanimat'sja svoim delom, každyj prinesët bol'še pol'zy. 'If everyone minds his own business, everyone will be more useful'

\section{[4.2] Arguments for LF movement}

There are at least two problems for Ivlieva's analysis. First, the laziness approach lacks generality. This becomes manifest once we switch from universal antecedents to those with different quantificational force (as suggested in Tiskin 2015). Besides každyj, vse 'everyone' and mnogie 'many' also give rise to 'lazy' interpretations, although in this case the anaphor should be plural. ${ }^{7}$

...esli by mnogie $_{i}$ iz nix žili sejčas, to oni ${ }_{i}$ opredelënno

if would many of them live now then they definitely ispol'zovali by komp'jutery Mac...

use would computers Mac

'If many of them lived now, they would be definitely using Mac computers'

Ivlieva's account, if extended to cover (16), would predict that oni should be interpreted as if a token of mnogie occupied its place. However, this yields incorrect truth conditions, according to which it is sufficient for the truth of (16) that some large subset of 'them' use Mac computers in case some (maybe other) large subset lives now. Meanwhile, the two readings (16) actually has are as follows:

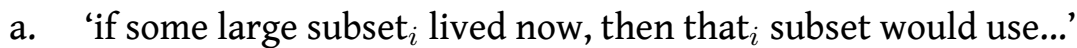

b. 'for some large subset: if any ${ }_{i}$ of those lived now, (s)he ${ }_{i}$ would use...'

[6] In addition to this, one has to account for the stronger reading. Ivlieva does this by manipulating situation indices (Barwise \& Perry 1983) on predicates: a situation may comprise only a fragment of a world, thus even in a world where not everyone minds their own business there is a situation whose domain of individuals is exhausted by those who do mind; what (13) says is that in such situations every individual in the domain is being more useful.

[7] An anonymous reviewer points out the similarity between (16) and cases of intersentential unbound anaphora such as (i). Here the pronoun they refers to the (maximal) set picked out by its antecedent. Plural anaphora is possible with universal antecedents, too. This weakens my first objection to Ivlieva, as two distinct analyses may be needed after all, depending on the number feature of the anaphor.

(i) $\quad$ Many students $]_{i}$ in my class passed the exam. They ${ }_{i}$ solved all the problems. 
Ivlieva's reading differs from (a) in that no anaphoric link is established between the subset mentioned in the conditional clause and that of the main clause ${ }^{8}$ so that it is incorrectly predicted that any large subset would do, not necessarily the one mentioned in the conditional clause. This problem would not arise under a binding-based approach.

The second problem is that without anaphora, as in (17), only the scoping 'if > $\forall$ is possible. This is not explained by any straightforward account based on the idea of laziness, as on such views it is unclear why the presence or absence of replaceable material in the second clause may have any effect on the interpretation of the material in the first clause.

(17) Jesli každyj opišet to, $v$ čëm on razbirajetsja, to v summe if everyone describes that PREP what he understands.well then in sum polučitsja velikolepnaja dokumentacija.

will.result brilliant documentation

'If everyone describes what he understands well enough, a brilliant documentation will result' (Google)

Although Ivlieva (2007) developed an analysis of (12)-like pgs in terms of covert movement, she does not consider the possibility of such an analysis for (13). Nevertheless, stipulating ATB movement for the strong reading does help, provided that a way is found to assimilate if-clauses to cases of coordination (as e.g. in Williams 1990). Then it would be possible to say that the quantifier moves ATB at LF9 out of both clauses if it occurs in both but cannot move if it only occurs in one. The weak reading will then have to be accounted for in terms of dynamic binding (Groenendijk \& Stokhof 1991; Kamp \& Reyle 1993), which will have to be extended onto universal quantification as well. The apparent problem tied to this analysis is how to explain that an overt pronoun is found in the second clause, which should

[8] Note that a distinctive feature of pronouns of laziness is their ability to support non-coreference:

(ii) This year the president is a Democrat. Next year, he will be a Republican. (Nouwen submitted)

[9] Despite the existing arguments against covert ATB movement (see e.g. Bošković \& Franks 2000), there is (albeit scarce) evidence for it, summarised in de Vries (to appear, § 2.2.7). 
not be expected of ATB movement, especially if it is covert. ${ }^{10}$

Regarding the latter problem, a reviewer has pointed out that the ATB analysis of (13) finds additional support in Bobaljik's (2002) architecture of interfaces. According to Bobaljik, who builds upon the copy theory of movement (Chomsky 1995, i.a.), either LF or PF have the choice of which copy to interpret and make their choices independently of each other. Thus, in (13), after the covert ATB movement of každyj, the upper copy is interpreted but the two lower copies are pronounced; an additional mechanism, perhaps close to that behind pronouns of laziness, replaces the second lower copy with a pronoun (see also (3)).

$$
\left[\mathrm{každyj}_{i}\left[\mathrm{esli}[\mathrm{každyj}]_{i} \text { budet...] [to [každyj }\right]_{i}{ }^{\text {on }}\right. \text { prinesët...] }
$$

However, if we go for an ATB analysis for (13) but allow for asymmetric extraction in the case of (9) and its kin, we run into a predicament. The reason is that free extraction out of adjuncts would result in the scoping ' $\forall>$ if' being predicted for (17) as well. A reviewer notes that one would have to formulate constraints on overt and covert movement differently in order to get this right.

\section{[5] CONCLUSION}

The wide availability of overt extraction from adjunct clauses in Russian suggests that the same mechanism may be at play in the cases where covert movement is semantically detectable. Following Bobaljik's proposal to endow PF with some amount of freedom as to which copy to pronounce, I have suggested that Ivlieva's cases of binding by universal antecedents from within a conditional clause be accounted for by means of covert ATB movement of the antecedent. The account dovetails with Ivlieva's treatment of $p g$-like configurations in Russian, but problems for such an account listed above are not negligible.

\section{ACKNOWLEDGEMENTS}

Thanks to the audience of the GRAMNORUS workshop in Oslo (April 2016) and to the two anonymous reviewers for OSLa, who provided thorough comments and important suggestions. The author is fully responsible for the remaining errors.

[10] Another instance of unbound anaphora to universal antecedents is telescoping (i), for which Keshet (2007) proposed a solution based on its semantics. In (i) anaphora is possible because the second sentence elaborates on the situation introduced in the first one, which allows Keshet to assume that the 'discourse continuity' between the two sentences in (i) makes them parts of a single overall structure where each degree candidate is able to bind the anaphor.

Although Ivlieva shows that her 'universal laziness' is licensed by 'eo ipso' semantics, i.e. by the fact that the situation of minding one's own business is itself the situation of being more useful, the analogy with telescoping is incomplete, as 'universal laziness' is hardly possible cross-sententially. (I am grateful to a reviewer for drawing my attention to it.) 


\section{REFERENCES}

Barker, Chris. 2012. Quantificational binding does not require c-command. Linguistic Inquiry 43(4). 614-633.

Barwise, Jon \& John Perry. 1983. Situations and attitudes. MIT Press.

Bhatt, Rajesh \& Roumyana Pancheva. 2006. Conditionals. In Martin Everaert \& Henk van Riemsdijk (eds.), The Blackwell companion to syntax, vol. I, 638-687. Blackwell.

Bobaljik, Jonathan David. 2002. A-chains at the PF-interface: Copies and covert movement. Natural Language \& Linguistic Theory 20(2). 197-267.

Bošković, Željko \& Steven Franks. 2000. Across-the-board movement and LF. Syntax 3(2). 107-128.

Chaves, Rui P. 2013. An expectation-based account of subject islands and parasitism. Journal of Linguistics 49(2). 285-327.

Chomsky, Noam. 1995. The Minimalist Program. MIT Press.

Culicover, Peter W. 1997. Principles and parameters: an introduction to syntactic theory. Oxford University Press.

Etxepare, Ricardo. 2013. On null complementizers in Spanish. Anuario del Seminario de Filología Vasca "Julio de Urquijo" 30(2). 469-496.

Groenendijk, Jeroen \& Martin Stokhof. 1991. Dynamic predicate logic. Linguistics and Philosophy 14(1). 39-100.

Ivlieva, Natalia. 2007. Parasitic gaps in Russian. In Richard Compton, Magdalena Goledzinowska \& Ulyana Savchenko (eds.), Annual workshop on Formal Approaches to Slavic Linguistics 15: The Toronto meeting, 132-140. Ann Arbor: Michigan Slavic Publications.

Ivlieva, Natalia. 2011. Universal laziness of pronouns. In Proceedings of SALT, vol. 20, 720-734.

Kamp, Hans \& Uwe Reyle. 1993. From discourse to logic: Introduction to modeltheoretic semantics of natural language, formal logic and discourse representation theory. Kluwer.

Keshet, Ezra. 2007. Telescoping and scope economy. In Proceedings of WCCFL, vol. 26, 324-331. 
Lakoff, George. 1986. Frame semantic control of the coordinate structure constraint. In Anne M. Farley (ed.), Papers from the parasession on pragmatics and grammatical theory, 152-167. Chicago Linguistic Society.

Lipták, Anikó. 2009. The landscape of correlatives:. In Anikó Lipták (ed.), Correlatives cross-linguistically, 1-48. John Benjamins.

Lyutikova, Ekaterina A. 2009. Otnositel'nyje predloženija s sojuznym slovom kotoryj: obščaja xarakteristika i svojstva peredviženija [Relative clauses with the relative pronoun kotoryj 'which': an overview and the properties of movement]. In Korpusnyje issledovanija po russkoj grammatike, Probel.

Nouwen, Rick. submitted. E-type pronouns: congressmen, sheep and paychecks. In Lisa Matthewson, Cécile Meier, Hotze Rullmann \& Thomas Ede Zimmermann (eds.), The Semantics Companion, Wiley.

Postal, Paul M. 1993. Parasitic gaps and the across-the-board phenomenon. Linguistic Inquiry 24(4). 735-754.

Roberts, Craige. 1989. Modal subordination and pronominal anaphora in discourse. Linguistics and Philosophy 12(6). 683-721.

Szabolcsi, Anna \& Marcel den Dikken. 2003. Islands. In Lisa Cheng \& Rint Syberma (eds.), The second GLOT International state-of-the-article book, 213-240. Mouton de Gruyter.

Testelets, Yakov G. 2001. Vvedenije v obščij sintaksis [General syntax: An introduction]. RSUH.

Tiskin, Daniel. 2015. Každyj možet i ne byt' lenivym [každyj 'everyone' may be not lazy]. Talk given at the 12th Conference on Typology and Grammar for Young Scholars. http://www. youngconfspb.com/application/files/ 6914/4821/8051/Tiskin.pdf.

Vicente, Luis. 2016. ATB extraction without coordination. In Christopher Hammerly \& Brandon Pickett (eds.), Proceedings of NELS, vol. 46, 1-14.

de Vries, Mark. to appear. Across-the-board phenomena. In Martin Everaert \& Henk van Riemsdijk (eds.), Blackwell companion to syntax, 2nd edn.

Williams, Edwin. 1990. The ATB theory of parasitic gaps. The Linguistic Review 6(2). 265-279.

Yoshida, Masaya. 2006. Constraints and mechanisms in long-distance dependency formation. University of Maryland. PhD dissertation. 
Zaliznyak, Andrey A. \& Elena V. Paducheva. 1979. Sintaksičeskije svojstva mestoimenija kotoryj [The syntactic properties of the pronoun kotoryj]. In Kategorija opredelënnosti-neopredelënnosti $v$ slavjanskix i balkanskix jazykax, 289-329. Nauka.

AUTHOR CONTACT INFORMATION

Daniel Tiskin

Saint Petersburg State University

daniel.tiskin@gmail.com 